\title{
Professional Development Strategies of College English Teachers from the Perspective of Educational Knowledge Management
}

\author{
Ge Liu \\ Department of Foreign Language Teaching and Research, Bohai University, Jinzhou, Liaoning 121003, China \\ Email:1g781115@163.com
}

\begin{abstract}
Educational knowledge management has been one of the research hotspots in educational technology. The applications of knowledge management and its interaction with educational technology are of great significance to the development of educational technology. Knowledge is the core of teachers' professional quality. The key to improving college English teaching quality is their professional development. If they do not pursue the professional development, they could be marginalized by the wave of teaching reform of English in China. At present, there are some problems in the professional development of college English teachers, with the continuous teaching theories and methods reform of college English. Moreover, the continuous innovation of professional knowledge and skills need to be managed by means of knowledge management. Through in-depth analysis and discussion of the problems of professional development of college English teachers, the professional development strategies of college English teachers are presented based on knowledge management.
\end{abstract}

Keywords: educational knowledge management, college English teachers, professional development strategies, educational technology, college English teaching reform

\section{INTRODUCTION}

Professional development of college English teachers has been given greater attention from the beginning of English language teaching reform of higher education in China in 2004. Professionalization of the college English teachers has been an important impact on their career planning and it can change the development trend of college English teachers' education [1]. The level of professional development of the teachers directly affects the quality of English teaching, and thus affects the realization of the goal of talents training. It can determine the success or failure of education to some extend [2]. The significance of knowledge management research is improving with the increasing of the importance of knowledge in social life. The field of education also needs the knowledge management. Most studies on professional development of college English teachers are focused on the personal dimension from a psychological or cognitive approach, such as the emphasis on individual teachers' reflective learning and reflective inquiry [2-5]. Educational knowledge management has been one of the research hotspot in educational technology. The applications of educational knowledge management and its interaction with educational technology are of great significance to the development of educational technology under the background of knowledge economy. It is of positive guiding significance to promote professional development of college English teachers to study the influence of knowledge management on their professional development and to explore the effective way of implementing their knowledge management. At present, there are some problems in the professional development of college English teachers, which need to be managed by means of knowledge management. Therefore, it is necessary to carry out the research on the professional development strategies of college English teachers from the perspective of educational knowledge management to meet the requirements of college English teaching reform in China, especially to improve the professional development level of college English teachers. Through in-depth analysis and discussion of the problems of professional development of college English teachers, the professional development strategies of college English teachers are presented based on knowledge management in this paper.

\section{RELATIONS BETWEEN PERSONAL PROFESSIONAL DEVELOPMENT AND THE KNOWLEDGE MANAGEMENT OF COLLEGE ENGLISH TEACHERS}

The professional development of college English teachers is not only the basic quality element of university education improvement, but also the necessary guarantee of teaching reform and education innovation [6]. Nowadays, the demands for the knowledge structures and level of the college English teachers are higher and higher. 
As far as the extensive knowledge of college English teachers is concerned, if the traditional means and methods are still used for knowledge management, it cannot meet the requirements of professional development of college English teachers. Knowledge management is particularly important in the professional development of college English teachers. The relations between personal professional development and knowledge management of college English teachers are discussed as follows. The professional development strategies of college English teachers are also presented based on knowledge management.

\subsection{Knowledge management helping college English teachers externalize tacit knowledge}

Normally, there are two kinds of human knowledge: explicit knowledge and tacit knowledge based on Polanyi's theory of knowledge [7]. Tacit knowledge is not specific, but does exist in every individual, and shows its unique role in analysis and judgment [7]. The personal knowledge management is conducive to the externalization of tacit knowledge of college English teachers. In the process of personal knowledge management, college English teachers should constantly think critically, revise and update their own knowledge base, externalize tacit knowledge into explicit knowledge, realize the teaching of professional English knowledge through classroom teaching. Personal knowledge is implicit in the knowledge structure of the college English teachers. Since the externalized knowledge can be preserved and spread in the form of text and speech, the externalization of the tacit knowledge plays an important role in the professional development of the teachers. Moreover, the externalization process of knowledge is also the innovation process of knowledge. Therefore, it is necessary to manage their knowledge by means of sorting, innovation, communication and sharing, so as to realize the externalization of tacit knowledge of the college English teachers.

\subsection{Knowledge management guiding college English teachers to innovate and strengthen knowledge actively}

The basic function of knowledge management of college English teachers is to initiate their innovative knowledge, improve their ability, promote their professional development, and help schools to complete knowledge accumulation and improve their competitiveness [8]. The essence of knowledge innovation of the college English teachers is to realize the interaction between the tacit knowledge and the explicit knowledge, so as to accumulate and update the knowledge in the process. In normal teaching practice, the college English teachers should analyze education activities step by step to innovate knowledge to ensure their stable professional development [8]. Personal knowledge management of the teachers is conducive to their knowledge structures, which tend to be reasonable and systematic, to the continuous enrichment of their own personal knowledge and the continuous improvement of educational wisdom. In conclusion, personal knowledge management of college English teachers is conducive to their knowledge structures, which could promote the effective professional development of college English teachers.

\subsection{Knowledge management improving college English teacher's personal theory}

Personal theory formed from the teaching thoughts or teaching theories of teachers through research, reflection, perception and internalization in the long-term teaching practice [8]. Through the accumulation of teaching experience and educational wisdom, college English teachers constantly enrich and construct personal teaching theory. In addition, college English teachers could have their own insights or situational experiences that conflict with existing concepts in education and teaching activities. A good habit of knowledge management is a sharp tool for the professional development of college English teachers. The ability of knowledge management of the college English teachers constitutes the core competitiveness of teachers. Efficient knowledge management of college English teachers can help them establish professional knowledge system, improve their professional knowledge structure and form their professional ability. Therefore, it is beneficial for college English teachers to renew their educational concepts, and improve their educational behaviours on the basis of improving their personal theories by strengthening knowledge management of the college English teachers.

\subsection{Knowledge management helping college English teachers dispel the inertia in their professional development}

In education and teaching activities of college English teachers, they can have their own insights or situational experiences, which may conflict with existing concepts. If they can record these insights in a certain form, analyze and reflect these insights or situational experiences, which are useful in generating their personal knowledge and theory, and make their professional lives highly active. Therefore, personal knowledge management can help them dispel the inertia in their professional development and radiate the vitality of their professional life. 


\section{THE STRATEGIES OF KNOWLEDGE MANAGEMENT FOR PROMOTING THE PROFESSIONAL DEVELOPMENT OF COLLEGE ENGLISH TEACHERS}

\subsection{Establishing and improving flexible knowledge service system of college English teachers}

The knowledge service system of college embodies the advantages of integrating knowledge, refining and classifying knowledge, processing knowledge and refining its value. Therefore, as an integrated and standardized organization, college has the responsibility and obligation to establish and improve flexible knowledge service system for college English teachers. Knowledge service system of college English teachers is an important strategy for the professional development of in-service teachers and the important parts of college English teachers' education. It also leads the professional development of college English teachers. In view of the differences of teachers' original cognitive level, individual needs and interests, colleges should provide flexible training modules for college English teachers, adopt the training form of faceto-face training combined with online learning, and take online learning as the platform to promote the knowledge management ability of college English teachers and help them develop their professional development. For example, in order to help the teachers build a platform for mutual learning and share their teaching experience and professional knowledge. Of course, it can also improve their professional level and promote their professional development through exchanges. During the period of comprehensive communication, college English teachers can deeply analyze the specific teaching situation, enhance their thinking activity, and find ways to deal with problems in analysis and research. In the process of observing and learning each other, they can further enhance their professional quality [9].

\subsection{Establishing a personal knowledge base to promote the professional development of college English teachers}

Abundant learning resources could be found in the network environments. They can help college English teachers filter and select information, participate in learning communities, which are conducive to their professional developments. Personalized knowledge management of the college English teachers transforms the public knowledge of learning communities into their individual knowledge, creates new knowledge with the help of learning communities, and realizes the development of college English teachers' personal professional knowledge. If the teachers can internalize their knowledge into personal knowledge, they can gradually improve the knowledge system and enrich the knowledge content. Therefore, college English teachers should actively manage their personal knowledge. When they store knowledge to the knowledge base, they should form a knowledge framework based on their own actual situation, sort out and summarize relevant knowledge, and establish their own unique experience. Therefore, establishing personal knowledge base of college English teachers could promote their professional development, increasingly develop and change knowledge society.

\subsection{Establishing a personal learning network to promote the professional development of College English teachers}

The establishment of college English teachers' personal learning network is actually their tacit knowledge management, which is embodied in the management of learning individuals and their learning partners, the establishment of smooth communication channels, and the socialization, communion and clarity of tacit knowledge. Professional college English teachers should understand their knowledge structure, filter, evaluate and integrate the existing professional information, and store it in the form of database, blog, media (video, slide, and tape), file, book reading notes, etc., so as to make the collected fragment professional knowledge become systematic information and form personal professional knowledge base. In teaching practice, they can consciously combine the fragmentary knowledge in the knowledge base into new knowledge, carry out curriculum design, and use certain teaching methods and means to complete professional English teaching tasks. In conclusion, the socialization under the network environment is more conducive to solve the personalized teaching problems of teachers, and establishing the personal learning network of teachers.

\subsection{Paying attention to the knowledge transfer process and promoting tacit knowledge of teachers' explicit knowledge}

The promotion of knowledge management to the professional development of the teachers is through the acquisition of knowledge by accessing, storage, sharing, application and innovation are realized by the college English teachers through these processes. Realizing the effective knowledge management of the teachers could promote their professional development. College English teachers can go through seminars, lectures, teaching workshops, networks, and other ways to obtain the required knowledge resources from the inside and outside college. Every college English teacher has a lot of knowledge, which formed from practical experience. Externalizing their personal knowledge is a method to promote their professional development. Cultivating the educational information of college English teachers under 
English teachers from the perspective of knowledge management.

effective way to promote the professional development of them. Exploring the methods to use information technology to promote foreign language teaching has been one of research focus of foreign language teaching reform [10-11]. In conclusion, the English teachers should pay attention to the transfer process of knowledge and promote tacit knowledge of college English teachers' explicit knowledge.

\subsection{Building the goal of life-long learning and improving professional autonomy of teachers}

The connotation of teacher professionalization is lifelong learning and development. Therefore, life-long learning is the basis of professional development of all college English teachers. Now, they are requested to enrich the knowledge gradually, studies the new teaching method, adapts the time development request. At the same time, teachers should form positive and farreaching ideals to promote self-development in continuous learning. Professional autonomy is the learner's scientific control of learning process. It is an important condition for the college to realize the professional development of college English teachers. They should also consciously reflect the learner's autonomy in the learning process. For every excellent teacher, they must have the ability of self-reflection, self-education and self-learning [2, 12].

\section{CONCLUSION}

Educational knowledge management has been one of research hotspots in educational technology. The professionalization of the teachers has an important impact on college English teachers' career planning and changes the development trend of teachers' education. Although their professional development could face many problems, for example, some colleges and teachers have never understood the role of teachers' professional development. The applications of educational knowledge management and its interaction with educational technology are of great significance to the development of educational technology. The key to improving college English teaching quality is their professional development. If they do not pursue the professional development, they could be marginalized by the wave of teaching reform of English in China. At present, there are some problems in the professional development of college English teachers. Moreover, the continuous innovation of professional knowledge and skills need to be managed by means of knowledge management. Based on the in-depth analysis and discussion of the problems in the professional development of college English teachers, this paper puts forward the professional development strategies of College

\section{ACKNOWLEDGMENT}

This work was supported by Education Science Planning Project of Liaoning Province in China (Project No. JG17DB).

\section{REFERENCES}

[1] B. Sun, Y. J. Gao, J. P. Yang, Elementary analysis on the professional development of professional English teachers through personal knowledge management, Journal of Higher Education, 2018 (18): $187-188$

[2] G. Liu. Enlightenment of teaching reflection on the professional development of College English teachers. DEStech Transactions on Social Science, Education and Human Science, 2017 pp.653-657

[3]Y. Zhao. Professional Learning Community and College English Teachers' Professional Development. Journal of Language Teaching and Research, Vol. 4, No. 6, pp. 1365-1370, DOI: https:// 2013 doi:10.4304/ jltr.4.6.1365-1370

[4] T. R. Guskey. Professional development and teacher change. Teachers and teaching, 2002, 8(3): 381-391. https://doi.org/10.1080/135406002100000512

[5] M. M. Kennedy, How does professional development improve teaching? Review of educational research, (2016): Vol 86, Issue 4, 945-980. https://doi.org/10.3102/0034654315626800

[6] Y. L. Hui. On the professional development of College English teachers based on personal knowledge management, New West, 2014,8:106-107

[7] H. Y. Lu, W. L. Zhang, Research on the professional development of tutors in open universities from the perspective of knowledge management. Think Tank Era, 2019, 48, 116-117.

[8] H. B. Zhang, M. Xiao The relationship between teacher knowledge management and teacher professional development, Comparative Study of Cultural Innovation, 2018, 2(20),134-135.

[9] X. Zhang, Research on the professional development strategy of university teachers from the perspective of knowledge management, Journal of the Chinese Society of Education, 2015, S2, 371-372. 
[10] G. Liu. Study on the Professional Development of College English Teachers in the Big Data Era. 3rd Annual International Conference on Modern Education and Social Science, 2017.

[11] G. Liu, Y. D. Qu. How to Improve Foreign Language Teachers' Application Abilities of Information Technology in Big Data Era. International Conference on Economics, Social Science, Arts, Education and Management Engineering. 2016.

[12] S. Civitillo, L. P. Juang, M. Badra, M. Schachner, $\mathrm{K}$. The interplay between culturally responsive teaching, cultural diversity beliefs, and self-reflection: A multiple case study. Teaching and Teacher Education, 2019, 77, 341-351. 